\title{
South Africa's Challenges of Realising her Socio-Economic Rights
}

\author{
Mohlapamaswi Mokgohloe Lorraine
}

University of Venda, South Africa

Rachidi Richard Molapo

University of Venda, South Africa

Rmolapo@univen.ac.za

\section{Doi:10.5901/mjss.2014.v5n27p900}

\begin{abstract}
Homelessness and poverty are huge challenges in South Africa. These social problems manifest themselves in poor housing. Inadequate and poor housing structures coupled with illegal land evasions as well as evictions have characterised the society since the Verwoerdian era and even during the new democracy. The ANC led government declared housing one of its constitutional mandate. Provision of the state's low cost housing is seen as a panacea to homelessness, inadequate housing and poverty. The fact that the democratic government declared housing a priority area, in itself gave birth to different perceptions in the minds of many people. Some people are occupying land illegally, which often municipalities will launch counter initiatives to evict them and take them to areas suitable for human settlement. Such an intervention is often fought fiercely by affected residents. There are people who believe that they can occupy any available vacant land because the Constitution of South Africa puts provision of adequate housing upon the state. This study used a qualitiatative research methodology in gathering data in the affected areas of Limpopo Province, South Africa. Providing housing continues to be contested and the battle does not seem to have been won. Despite the challenges of the state, a framework has been established for the future.
\end{abstract}

Keywords: Homelessness, apartheid, mekhukhu, democracy and South Africa

\section{Introduction}

South Africa as a developing country has a housing market that is skewed. The country experiences a huge housing backlog, which is often a distinct character in all developing countries. Developing countries attribute their inadequate housing and poor infrastructural development to underdevelopment. The Neo-Marxist theorists, most of whom may be regarded as proponents of the dependency theory in one form or another claimed that imperialism and colonialism have impeded progress throughout the Third World (Martinussen, 1997). This creates unequal relations between developed and developing countries. The unequal power relations between developed and developing countries has a negative impact on service provision in less developed countries like South Africa. In addition, South Africa was subjected to Verwoedian system which promoted migrant labour system. The migrant labour system created a need for housing in towns and cities. When more people travel to the cities in search of jobs, they were confronted with a critical housing shortage. They then came up with alternative means to construct cheaper housing structures. These people constructed dwellings from all varieties of materials which are frequently unsuitable for construction designs. For example, they use tins, pieces of plastic and low quality wood (Cloete, 1993). The use of unsuitable building materials to erect houses are equally a consequence of poverty and landlessness.

The Verwoedian government fought the shack dwellers with all its power. This created conflict between black people and the Verwoedian administration. The apartheid government resorted to evictions, removals and the enforcement of the Group Areas Act of 1950. The evictions affected the political landscape of the country. People's hopes rested in the violent conflicts which tragically characterised so many informal settlements since the mid-1980s (Smith, 1992). Evictions failed to resolve the problem of informal settlements as evictees continued to invade spaces near cities and forcefully sought to be part of the city settlements. The landless always resort to violent means to fortify their stay on invaded land. While some especially class issues were taken up, the campaigns, as a whole, were not overtly class based, on the common oppression of black people, especially African people under white rule (Marks, 1987). The unequal power relations between developed and developing countries further spiralled to unequal level of development 
between rural and urban areas. Rural areas suffer defective infrastructure such as bad road conditions and inadequate housing.

\section{Housing and Democracy in South Africa}

During the apartheid era, the South African government did not prioritise the provision of housing. The Housing Act of 1966 declared that the local authorities should not be seen as housing institutions. The Act stated that it should remain the responsibility of every citizen to provide his/her own house (Cloete, 1993). This led to people constructing inadequate housing structures as they did not receive subsidies from the government and contributed immensely towards housing backlog and homelessness in South Africa. After South Africa's new democratic government, there is still a rapid spread of informal settlements and the mushrooming of shack settlements as people want to be near the cities and their places of work.

Subsequently the first democratic elections in South Africa, people threw their own expectations of service delivery. Housing has always been high on the expectation list of the people. The African National Congress led-government has since 1994, been addressing the issue of the housing backlog and placed it high on its development agenda. The enactment of the Housing Act 107 of 1997, South Africa's housing policy, and other related housing legislation, sought to address the imbalances of the past through the provision of adequate and habitable housing, specifically to the poor. It is through the legislative processes that government strives to establish socially and economically integrated communities. The policies commit the government to a mass delivery of 1 million homes in five years, a person-centered housing processes which prioritise the needs of the poor and vulnerable groups, and the delivery of a decent product with access to public services and amenities (Khan, 2003). The challenge with many settlements in South Africa is that they are devoid of amenities and essential infrastructure such as water and electricity to mention a few.

The South African government, however, established the National Home Builders Registration Council (NHBRC) to promote construction of housing structures of better quality and further protect the poor against unscrupulous contractors, however the quality of the houses provided by the government to the poor remains criticised.

\section{Literature Review}

There are different views as to the cause of the housing backlog in South Africa. There are those who assert that the current housing shortage in South Africa is a by-product of natural population growth, whilst others attribute the critical housing shortage to migration and restrictive apartheid legislation. Some believe that all the three factors, natural population growth, migration and apartheid laws have contributed immensely to the current state of housing (Mashabela, 1990). The South African housing backlog is traceable to the period beyond 1945 when the National Party came to power. The National Party passed laws that discouraged provision of housing for the blacks. In addition to criminalising African job seeking activities, a deliberate policy of not providing family housing was pursued to discourage the permanent settlement of those Africans escaping the pass law net. The only approved accommodation for oscillating migrants was the hostels, or more precisely, labour compounds (Ramphele, 1993). Fundamentally, the provision of housing was based aolong racial lines. Whites were afforded adequate housing, whilst blacks were left to fend for themselves. Their movement to the cities was also discouraged through the pass laws, thus inhibiting their ability to house themselves. They were forced to stay in poorly built structures outside the white residential areas, in proximity to the city, thus enabling white people access to cheap labour without the burden of excess infrastructure.

It was after the National Party came into power that the policy of separate development, 'apartheid', was implemented and intensified. The period 1950 saw a government's concerted effort to segregate people along racial and ethnic groupings. The enactment of the Group Areas Act of 1950 ensured that people of different races and cultural groups were zoned into different exclusive residential areas. The exclusive nature of residential zones led to inequalities in housing.

Mixed racial settlements were forbidden by the law, making it a criminal offence to reside in a 'mixed' residence. In the minds of White officials, the apartheid city has always been imagined and naturalised as an organic entity; a body susceptible to contamination and disease by the infiltrations of uncivilised Africans, the metaphorical germs creating the festering sores of the 'septic fringe'. Sanitising the city, cleansing it of impurities, has been a central ritual of renewal for the apartheid urban order (Manona, et al. 1996). It is for that reason that all blacks in the country were from the rural Bantustans, and all cities and towns were exclusively for white people. The dichotomy of separate development was that all rural Bantustans were poor, whilst the white people in the cities had economic opportunities such as jobs and infrastructure. The rural residents, all blacks, lived in abject poverty, whilst the bulk of the white people benefited from a 
racially biased system. The blacks were driven by their socio- economic position to relocate from rural areas to the cities to serve white interests. This culminated in white supremacy, with blacks regarded as inferior and whites as superior. Even in the workplace, whites would occupy higher positions whilst blacks, who made up $76 \%$ of the population, were only given menial jobs and positions of less responsibility and influence (Knight, 2001). The black population served the whites and was subjected to exploitation. It is on account of their poor socio-economic circumstances that black people became subservient.

It is as a result of codified segregation that during the apartheid era, people lived in abject poverty and could not afford basic needs such as housing, land and clean water, as they were largely unemployed. This subjected the majority of people, especially blacks, to dire poverty. They were homeless, landless, and lacked essential amenities such as clean water, sport and communication facilities to name only a few. Poverty and unemployment, both social ills, evident in the black population during the apartheid era translated itself into poor living conditions and low socio-economic status in black communities. Poverty made it difficult for the black people to adequately house their families. This resulted in black people living in uninhabitable houses without water and electricity both in the rural areas and in the cities. Pangs of hunger forced black males to move to the cities in search of employment, in order to alleviate poverty.

When the black males moved to the cities and towns of South Africa, they were met with the harsh reality of a critical housing shortage. This contributed to a vast number of migrant laborers resorting to hostels as a kind of alternative accommodation or housing, all this because the government did not supply lodging for people from the rural areas. Their stay in hostels was never an option. They were forced to stay in hostels, as there was no variety in housing to choose from.

The construction of the hostels, and the regulations governing such housing, were provided for under the Natives (Urban Areas) Act 21 of 1923, which amongst other things, was motivated by the need to ensure that further labour requirements be met by housing African men in hostels and barracks in urban areas. These were employed as instruments to exclude undesirable Africans from the cities and towns. The building of the hostels and compounds was a conscious political effort exercised by the government to encourage a class society based on race and gender. The construction of hostels in South Africa was not meant to provide housing for the working class, but it was meant to achieve political objectives for government. This was basically intended to prevent black participation in the mainstream economic system. The construction of hostels created conflict between labour and capital.

Hostel dwellers, both as migrant workers and as Africans, were excluded through racial discrimination policies over the years from effective participation in the political and economic institutions of South Africa. Their mobility was also circumscribed by legislative means until the promulgation of the Abolition of Influx Control Act of 1986 (Ramphele, 1993). The condition of being both a hostel dweller and an African greatly disadvantaged black workers. These Acts impacted negatively on the supply of housing country wide. Hostels were built in towns and cities across the country to serve the state's political agenda and to promote white capital.

They were a logical outcome of the process of conquest (Ramphele, 1993). Since hostels have been part of the black South Africa for decades, one can forgive the current government if it takes them decades to fully address the current housing backlog. The current housing backlog, due to the fact that it was orchestrated for decades, may not be addressed completely within a few years. Thus the struggle to provide adequate housing for blacks is still a huge challenge, especially in the cities.

The periods 1958 and 1978 were characterized by the government's further attempt to achieve 'territorial segregation' in the housing environment along racial lines. The Urban Local Authorities were encouraged to provide only hostels for migrant African labourers. The result was that Africans had to share their hostel rooms with others, and this caused a lot of tension because of lack of personal privacy (Mutshinyali, 2000). It is evident, therefore, that the housing of laborers in the hostels, in itself, had negative implications for the welfare of laborers. It meant that workers, after a hard day's work, had to go to crammed tiny rooms allocated to them in the hostels. These rooms hardly had any facilities to relax. This was different from what their white counterparts had.

White workers were never housed in the hostels. They had their own spacious homes to live in with their families. The apartheid government provided adequate housing for white people. Housing was more of a problem for the black population than for white people. The skin colour of a person in South Africa was a determinant factor in the provision of adequate housing. The darker one's skin was, the grimmer the chances of adequate housing became.

Hostel rooms impacted negatively on 'Black' productivity, subsequently on their mental well-being and health, as the rooms were shared and small. The fact that 'space' in the hostel was small and shared resulted in sour relations amongst black migrant workers across the country and in neighbouring states. Hostels were a centre of conflict, which often ended tragically. Labourers fight and, sometimes, kill each other. The consequences were that those people in the rural areas, who depended on hostel dwellers for survival, were plunged into further poverty that made it difficult for them 
to satisfy basic needs.

The labourers were poor in space, and poorer in attaining human dignity as the hostels were literally like cages. The hostel system, therefore, subjected black labourers to all forms of economic, social and spiritual poverty. The only way for a hostel dweller to get a space allocation in the hostels was through securing a bed. It meant that the life of any hostel dweller in South Africa, during the apartheid era, was defined by a bed, and it was wholly dependent on it. One's very identity and legal existence depended on one's attachment to a bed. A person would only become a hostel resident only if he has a bed allocated to him in a hostel.

The bed gave meaning to life, and a symbol of intense poverty and lack of economic freedom. This boiled down to resource constraints that prohibited black males from housing their families adequately. A 'bed' conjures the image of space. Space is still a challenge to the ANC-led government today as land is a limited resource.

The hostel dwellers suffered economically because their rooms were barely furnished. They were small and too basic. They were equally socially restrained, as they were not allowed to live with their girlfriends, spouses or children until the late 1960s. Most hostels were male residences and females were not allowed to stay in such exclusive residences. Women, even if they were married, were not permitted to visit their husbands in the hostels.

Some of the male hostel dwellers cohabited with women in the townships as a way of getting alternative accommodation. They got a sense of family again, something hostels deprived them of. Townships were convenient, and closer to their workplaces. The cohabitation practice led to some hostel dwellers abandoning their wives and children in the rural areas. They shunned their responsibilities. This did not happen because the hostel dwellers were irresponsible, but because they were pressured to come up with ways and means to sustain themselves in the cities. Such practices, for them, were survival strategies. They had to develop strategies to cope with life under white rule.

These males would cut off all forms of contact with their families and shrug off their financial responsibilities. The hostel culture was embedded in a system of mentorship by older residents. However, some of the young hostel dwellers fell through the cracks due to lack of support or a refusal to be controlled by others, alcoholism or loss of contact with the rural base. This ruined many lives. It is during the era of the hostel systems that a new breed of names emerged: makgolwa in Northern Sotho, ushiphile in Xhosa or ibhunguka in Zulu, makholwa in Xitsonga. All these names were given to men who had left their homes in search of work in the cities, whilst there had found new women and abandoned their families. Such abandoned families would struggle to make ends meet and would not be able to look after their housing needs. Such men exacerbated poverty in the rural areas as their wives and children were abandoned and subjected to deprivation, abject poverty and intense vulnerability. Poverty rose rapidly in the rural areas as a result. This, amongst other factors, has led to the African National Congress-led government inheriting a legacy of poverty and housing backlog. The hostel system contributed immensely to the current housing backlog.

Such remnants of the hostel system look to the state to provide housing for them either in the form of old age homes or the state's low cost housing. They also add up to the pool of people who expect the state to adequately house them. This puts a strain on effective service delivery country wide. This is the reason why, after 18 years of democratic society, the South African government still grapples with the issue of housing shortages and informal settlements. The housing backlog is still a challenge today and most poor people are still in the housing list, waiting for government to provide low cost houses for them.

This is because the demand for housing has increased rapidly. The pre-democratic policies consciously and deliberately did not address the housing needs of the Black South Africans. Instead the apartheid government was more determined to create exclusive residential areas. The concerted efforts of the apartheid system to separate people along racial lines led to a massive housing backlog amongst black people in the country. The apartheid policies of residential segregation and the migrant labour system did lasting damage to South African family life. The policies created a legacy of fractured families. A study conducted by the Umkhanyakude on Child Support Grant revealed that some children who receive grants have 'missing' fathers (Padayachee, 2006). Missing fathers are those fathers who are not known to be dead, but their whereabouts are not known to be dead, but their whereabouts are not known either. The study attributes the 'missing fathers' to both apartheid and the migrant labour system, as these promoted family separation (Padayachee, 2006). This shows the extent to which the black population endured economic suffering, which affected their capacity to provide housing for themselves.

The enactment of repressive laws such as the Native Urban Affairs Act of 1923 and the Group Areas Act of 1950, as well as the hostel system exacerbated the housing backlog countrywide. This resulted in separate residential locations of poor standards and the establishment of uninhabitable living areas such as Sophiatown in Johannesburg. Ironically, such uninhabitable living areas attracted throngs of black migrant labourers because they were convenient and closer to the factories and their workplaces.

A rise in the demand for labour in cities is traceable to the World War 2. The rapidly increasing demand for labour 
during this period attracted a high number of African migrant labourers to urban areas (Mutshinyali, 2000). The result is that informal settlements, shacks and squatter settlements mushroomed as black workers, in large numbers, forcefully occupied pieces of land nearer to cities and towns so as to be nearer to their work places because they were not wanted in cities.

\section{The Reconstruction and Development Programme}

The housing backlog reached alarming levels in 1994, when the ANC-led government assumed power. Government inherited a housing backlog that affected the black population mostly. The government introduced the Reconstruction and Development Programme to address the imbalances of the past. The RDP as it is commonly known is based on the Marshall plan. The Marshall plan is a brain child of General George Marshall who, in 1947, argued that the European economy needed regeneration after the devastation and destruction of infrastructure caused by the Second World War. Marshall Aid took the form of fuel, raw material, goods, loans, food, machinery and advisers. It jump started rapid European economic growth (Clare, 2000).

The objective was to pursue growth and development through reconstruction and redistribution. The plan promoted a leading and enabling role for government to guide a mixed economic system. It prioritised the meeting of basic socioeconomic needs of the poor majority and argued for a living wage as a pre-requisite for achieving the required level of economic growth. It aspired to attain a people-centered society.

The RDP, the South African development policy, is based on five key programmes or objectives, namely: meeting basic needs, developing human resources, building the economy, democratising the state and society, and implementing the RDP. It is through the RDP programme that the government wants to eradicate poverty and provide a better life for all (ANC, 1996a). The Reconstruction and Development in its aspiration, envisaged a society in which the poor will be able to satisfy their basic needs, such as water, food, housing, and employment

The basic needs of the people refer to jobs, land, housing, water and transport (Matlala, 2000). The main purpose of the RDP was and still is, to alleviate poverty by guaranteeing that the poor satisfy their minimum basic needs. Basic needs are survival needs, needs that people can hardly survive without. It is one objective of the ANC-led government amongst others, in the RDP document, to provide adequate shelter to the section of the population that cannot do so for itself, hence the state's low cost houses are commonly known as the 'RDP houses'. These houses are meant to benefit mostly the previously disadvantaged individuals such as black women and the disabled.

The RDP as a developmental programme in providing the state's low cost housing is a constitutional mandate. The Constitution of South Africa, Act no 108 of 1996, section 26 declares that everyone has the right to have access to adequate housing, and that the state must take a reasonable legislative and other measures within its available resources, to achieve the progressive realisation of this right. It is a state obligation in South Africa that, because the poor cannot provide adequate housing for themselves, such a burden be transferred to the state. It becomes mandatory on the part of government to build houses for the economically disadvantaged persons in order to alleviate poverty and to eradicate informal settlements and shacks. The agenda of government is to provide a quality life for all citizens of South Africa. This mandate has been reassigned to the nine provincial governments of South Africa to execute on behalf of the government. It is the responsibility of each province to meet the housing needs of its population. The vision of the national Department of Human Settlements is that by the year 2030 all people of South Africa should be adequately housed and accommodated in a decent, secure, viable and affordable housing environment.

\section{The 1994 Election Manifesto}

The ANC election manifesto of 1994 prioritised education, housing, employment and healthcare. The election manifesto emphasised the need to provide adequate housing for the entire nation, hence the slogan "Housing and Services for all". The ANC committed itself through the 1994 election manifesto to ensuring that everyone has a roof over his/her head. The manifesto declared that reasonable living conditions are not a privilege (ANC, 1996b). They are basic rights for every human being. The implication of the 1994 election manifesto is that government is capable and prepared to provide adequate houses for everybody in need. This is, however, problematic as there are cost implications.

The aspiration of the ANC in the 1994 first democratic elections, were ambitious as by then 17 million people lived below the poverty datum line in South Africa and, of these, at least 11 million lived in rural areas. Amidst the ravaging poverty that existed then, the ANC, through the RDP, committed itself to redistributing a substantial amount of land to landless people, building over one million houses, providing clean water and sanitation for all, electrifying 2.5 million new homes, and providing access for all to affordable healthcare and telecommunications. The government wanted to 
accomplish all this in five years (ANC, 1996a). The problematic part of this ambition rested in the availability of state funds to finance the projects and to build adequate houses for the poor. The problem is not simply the money to build such houses, but the availability of land, as not all the land is state-owned. In the rural areas, chunks of land belong to the traditional leadership.

\section{The Challenges Faced by the ANC-led Government}

Land ownership in the rural areas is a challenge for the ANC-led government. Land in the rural areas is owned by the traditional leadership. There are often conflicting interests between government and the traditional leadership in terms of development programmes in rural areas.

Most people are not attracted by the rural areas. Rural areas do not offer equal opportunities as cities do. People continue to move to the cities in great numbers, thus contributing to the increased population density in cities. The urban bias has serious implications on rural provinces of South Africa. A large number of people leave rural provinces for 'industrialised' provinces such as Gauteng, Mpumalanga and the North-West in search of greener pastures. The migration to these provinces results in a brain drain and skills shortage in the poorest provinces.

The migrant labour system has created a situation where families stay as separate entities. Most households are either female headed or child headed as most males have relocated to the cities, leaving children or wives to fend for themselves. There is a dire need to redress the problems created by the apartheid system. Apartheid has disenfranchised families. The relocation of people and families closer to their employment is a huge challenge.

The movement of people from the rural areas to urban areas would continue, thus putting a huge strain on the infrastructural capacities of various cities across the country. This is mainly because the rural areas are under-resourced and under-developed. The urban bias is perpetuated by the government and impacts negatively on housing in the cities. People are, consequently, forced to occupy land illegally and create shacks and tin settlements. Mekhukhu, the name for shacks used by Harry Mashabela denotes a sense of temporary settlements. Over time, they have acquired the stature of permanent settlements through resistance. The challenge faced by government is how to upgrade the informal settlements. The settlements need social amenities such as schools, water, clinics and roads to make them habitable and suitable for human settlement.

The majority of the people who were allocated RDP houses are unhappy with the houses. Criticism of the houses includes the quality and size. Some RDP houses are so small and badly built that people joke that they are so small you need to go outside to change your mind (Knight, 2001). This contributes towards people not taking pride in the ownership of the houses and some resorting to either selling or abandoning the houses. Government needs to improve both the size and the quality of the houses. This would, nonetheless, put strain on public sector spending. Some owners of the RDP houses do not have a sense of pride in owning the houses. They are not well-cared for, they end up dilapidated and unsustainable. There is need to awaken a sense of appreciation and ownership in the people.

Most people in South Africa $(24,1 \%)$ are unemployed and most of the time look for menial jobs in the cities and often tempted to turn their state's low cost houses into money generating ventures. If the beneficiaries of state's low cost housing rent out their houses for money to non-beneficiaries, whether local or foreign, the exercise boils down to the defeat of the stated objectives and its vision. It is, therefore, going to be difficult for the state to eradicate shacks and informal settlements by 2030 if South African citizens are the ones frustrating the efforts of their government. It is going to take the South African government beyond 2030 to eradicate shacks and informal settlements, given the fact that a person qualifies once for a low cost house. Those who sell their houses will forfeit their chances to own a house infinitely. Also the ill practices in the low cost housing, the time frame to adequately house the residents of South Africa by the year 2030 is too short, whilst the nation's unemployment rate stays high.

The vision to eradicate shacks and informal settlements is a constitutional prerequisite. The Constitution calls for government to address the housing needs of its population. It signifies that the most wretched of the poor in South Africa have a right to be furnished with adequate housing by the provinces. The provision of low cost housing is, thus, a rudimentary role of government. In South Africa, the provision of low cost housing is not exclusively the function of government, but it is likewise a major focal point of government in post-apartheid South Africa. It is the government's core function to address the historical inequalities, poor municipal service provision, and contemporary rapid urbanization.

The White Policy on Housing 1994 prioritized the needs of the poor, encouraged community participation and involvement of the private sector, and committed the government to the delivery of 1 million houses in five years. By early 2006, 1877958 housing units had been constructed or were under construction, according to the Department of Housing (Khan \& Thring, 2003).

Amidst the challenges confronted by the state, the challenge with South Africa's low cost housing development is 
the location in which these homes are constructed. They are mostly built on serviced townships and urban peripheries (Khan \& Thring, 2003). If this development persists, beneficiaries of low cost housing will continue to move out of these houses and erect shacks near the cities as a way to be nearer to resources and potential work opportunities.

The government has embarked on completing the blocked or unfinished projects. By 2007, about 7,000 units have been completed in one of South Africa's poorest provinces, Limpopo Province (Department of Local Government and Housing, 2008). State intervention in rebuilding the houses has cost implications for the state. The use of inadequate construction materials is also a troubling development. The quality of bricks used to build low cost houses often do not meet the South African Bureau of Standards requirements. If some contractors use bricks of poor quality, it is likely that those houses will collapse in the near future, are therefore, likely to injure or kill the occupants.

\section{Reasons for the Abandonment of Houses}

Most of the houses built in the country, especially in Limpopo Province, one of South Africa's poorest provinves, are small. The space in any household is a determinant of privacy or lack of it in the house. If houses built by the state are as small as 32 square meters, then such a household is deprived of its constitutional right, which is the right to privacy.

The small size of the houses is one reason amongst many, why some beneficiaries rent out or abandon their houses. The abandonment of such houses impacts adversely on the provision of low cost houses and contributes to a rise in criminal activities in some areas. When some people abandon their houses, criminals seize them, thus turning some of the houses into havens for criminal activities.

Housing differs in type, size and design. Whatever form it takes, there is a need to measure its quality to ensure that it satisfies the residents' family and cultural norms. People put privacy at the crest of their priority list. They will, therefore, opt for human dwellings that offer them adequate space without feeling that their private space has been invaded. The housing quality can be quantified through objective and subjective approaches. Objective measurement of housing is widely used and it evaluates the physical characteristics, facilities, services and environment, however, objective assessment is not able to examine and explain the psychological aspects of resident satisfaction. Subjective measurement which includes perception, satisfaction, aspiration and also a disappointment, is closely related to the psychosocial aspects of a person (Sallen, 2008). If people are not satisfied by the structural component of their houses, such people are likely to abandon or neglect their houses, a trend taking place in provinces across the country.

\section{Conclusion}

Providing shelter for the poor people of the country is a challenge to the government. A trend that developed from the colonial lapartheid years has created a huge housing backlog for the present government. Under a Constitutional democracy, the government is obliged to provide houses to those people who the major financial institutions do not have interest in uplifting their plight. Although given this Constitutional obligation, the major courts are aware of the resources constraints facing the government.

\section{References}

ANC, 1996a Election Manifesto of the African National Congress. Available at www.anc.org.za. Accessed date 11/08/2013

ANC, 1996b.Reconstruction and Development Programme. Available at www.anc.org.za. Accessed date 11/08/2013

Clare J.D. 2000. The Marshall Plan. Available at www.johnclare.net. Accessed date 23/05/2012

Cloete J.J.N. 1993. Towns and Cities. J.L van Schaik Publishers, Pretoria, p. 67

Khan F. And Thring P. 2003. Housing Policy and Practice in Post-Apartheid South Africa, Sandown: Heinemann Publishers

Knight R. 2001. Housing in South Africa. Available at http://richardknight.homestead.com/files/sisahousing.htm. Accessed date: September 2011

Manona C. et al. 1996. Informal settlement in the Eastern Cape, South Africa, Pretoria: Institute of South African Studies

Marks S. 1987. The politics of Race, Class and Nationalism in Twentieth century South Africa. Longman Inc, New York, p.369

Martinussen J. 1997. Society, State and Market. Human Sciences and Research Council, Pretoria. Pp. 38-86

Mashaba S. 2012. Madonsela Urged to probe RDPs rot, Sowetan, 22 August 2012

Mashabela H. 1990. Mekhukhu: Urban city of the future. Pretoria: South African Institute of Race Relations

Matlala M.M. 2000. Low Cost Housing Delivery in the Northern Province with reference to the Central Region

May J. 2000. Poverty and Inequality in South Africa: Meeting The Challenge, David Philip Publishers, Claremont, p. 29

Mutshinyali I.P. 2000. The critique of the implementation of the Housing Policy through housing Project as a means to alleviate homelessness and Poverty in the Northern Province, with specific reference to the Mhinga Housing Project

Padayachee V. 2006. The development decade?, Economic and social change in South Africa, Pretoria: HSRC Press 
Ramphele M. 1993. A Bed Called Home, Claremont: David Publishers

Sachs, Albie, The Strange Alchemy of Life and Law, Uk, Oxford University Press, 2009, chapter 7, The Grootboom Case.

Sallen A.G. 2008. Urban and rural human settlement. Habitat International. Vol. 08

Smith D. 1992. The apartheid City and Beyond, Witwatersrand University Press, Johannesburg, p. 2-27

Stats SA, 2006. Statistics South Africa, Provincial Profile 2004 Limpopo Province, Statistics South Africa, Pretoria, p. 2

Unhabitat, 2004. Housing as a strategy for poverty reduction for Ghana. Available at www.Unhabitat.org. Accessed date: 23/07/2012 